\title{
SZCZEGÓLNE PROBLEMY UBEZPIECZENIA SPOLECZNEGO ZLECENIOBIORCÓW W KONTEKŚCIE BRAKU BEZWZGLĘDNEGO OBOWIĄZKU OSOBISTEGO ŚWIADCZENIA PRACY PRZEZ ZLECENIOBIORCE
}

\begin{abstract}
Streszczenie. W artykule przedstawione zostały specyficzne problemy ubezpieczenia społecznego zleceniobiorców wynikające z braku bezwzględnego obowiązku osobistego świadczenia pracy przez zleceniobiorcę. Analizie poddane zostały sytuacje, w których zleceniobiorca wykonuje zlecenie przy pomocy osoby trzeciej lub jest przez tę osobę zastępowany. Omówiono skutki korzystania przez zleceniobiorcę z pomocy innych osób w sferze ubezpieczenia społecznego dla samego zleceniobiorcy oraz jego pomocnika, podwykonawcy lub substytuta. Została również omówiona konstrukcja osoby współpracującej przy wykonywaniu umowy zlecenia.
\end{abstract}

Słowa kluczowe: ubezpieczenie społeczne, zleceniobiorca, umowa o pracę, umowa zlecenie.

Zgodnie z art. 6 ustawy z 13.10 .1998 r. o systemie ubezpieczeń społecznych (Dz.U. z 2017 r., poz. 1778 ze zm.) ubezpieczeniem są objęte m.in. osoby wykonujące pracę na podstawie umowy agencyjnej lub umowy zlecenia albo innej umowy o świadczenie usług, do której zgodnie z Kodeksem cywilnym stosuje się przepisy dotyczące zlecenia, zwane dalej „zleceniobiorcami”.

Omawiając regulacje z zakresu ubezpieczeń społecznych, powszechnie posługujemy się terminami „umowa zlecenia” i ,zleceniobiorca”. Musimy jednak pamiętać, że na ogół nie chodzi tutaj o umowę zlecenia w ścisłym cywilistycznym rozumieniu. Zgodnie bowiem z art. 734 § 1 ustawy z 23.04.1964 r. - Kodeks cywilny (Dz.U. z 2018 r., poz. 1025 ze zm.), przez umowę zlecenia przyjmujący zlecenie zobowiązuje się do dokonania określonej czynności prawnej dla dającego zlecenie. W ubezpieczeniach społecznych mamy natomiast do czynienia z umowami, o których mowa w art. 750 Kodeksu cywilnego, tj. z umowami o świadczenie usług, które nie są uregulowane innymi przepisami i do których stosuje się odpowiednio przepisy o zleceniu. Można uznać, że ustawa systemowa zawiera własną definicję ,zleceniobiorcy” na użytek ubezpieczeniowy, która obejmuje osoby wykonujące pracę na podstawie wszelkich umów nienazwanych zbliżonych do typowej umowy zlecenia, których przedmiotem jest świadczenie usług.

*ZUS I Oddział w Łodzi, asia.ceg@wp.pl 
Zleceniobiorcy są szczególną kategorią ubezpieczonych, usytuowaną pod względem faktycznym i prawnym pomiędzy pracownikami a osobami prowadzącymi działalność gospodarczą. Specyfika pracy wykonywanej w oparciu o umowę zlecenia powoduje, że prawidłowe ukształtowanie zasad ubezpieczenia społecznego zleceniobiorców nie jest łatwe.

Należy podkreślić, że zleceniobiorcy są grupą bardzo zróżnicowaną. Jak wskazuje się w doktrynie, umowy zlecenia można podzielić na dwie grupy: zachowujące swój pierwotny, cywilistyczny charakter oraz kreujące faktyczne zatrudnienie, tj. stanowiące podstawę do osobistego świadczenia pracy na rzecz jednego podmiotu, będące jedynym źródłem przychodu, niewiążące się z prowadzeniem działalności gospodarczej i mające charakter względnie trwały (Babińska-Górecka 2015, 41-42).

Zleceniobiorca, tak jak pracownik, wykonuje pracę najemną. Wykonuje czynności na rzecz innego podmiotu i za to otrzymuje określone wynagrodzenie. Umowa zlecenia jest umową starannego działania, choć w umowie może być przewidziane dodatkowe wynagrodzenie za osiągnięcie oznaczonego rezultatu (wyrok SN z 16.02.2006 r., IV CK 380/2005, LexisNexis nr 1354974; wyrok SN z 14.01.2010 r., IV CSK 319/2009, LexisNexis nr 2447022; Palestra 2010, nr 1-2, s. 264). Ryzyko gospodarcze niewystąpienia rezultatu obciąża dającego zlecenie. Podkreślić należy, że przyjmującemu zlecenie należy się wynagrodzenie również w sytuacji, gdy zlecona czynność nie została dokonana, jeżeli wykaże, że dołożył należytej staranności w celu wykonania umowy (był gotów do jej wykonania), zaś niedokonanie czynności nastąpiło na skutek okoliczności, za które nie ponosi odpowiedzialności, w szczególności wskutek przeszkód spowodowanych przez dającego zlecenie (wyrok SA w Warszawie z 24.08.2012 r., I ACa 67/12, LEX nr 1220685; wyrok SA we Wrocławiu z 22.03.2012 r., III AUa 1265/11, LEX nr 1164105). W umowie zlecenia strony mogą w większym stopniu niż w umowie o pracę (a nawet całkowicie) uzależnić wysokość wynagrodzenia od realizacji zadań lub osiągnięcia określonych wyników, jest również dopuszczalne całkowite wyłączenie z wynagrodzenia składników stałych (Prusinowski 2012, 37).

W odróżnieniu od pracownika, zleceniobiorca nie wykonuje pracy pod kierownictwem oraz w miejscu i czasie ściśle określonym, ale co do zasady samodzielnie decyduje o sposobie wykonania czynności. Zakres tej samodzielności jest wyznaczany przez treść umowy, wskazówki dającego zlecenie oraz cel i charakter podejmowanych czynności (Drapała 2013). W wyroku z 11.09.2013 r. (II PK 372/12, OSNP 2014/6/80) SN orzekł, że w umowie zlecenia mogą wystąpić cechy kierownictwa i podporządkowania, choć nie takie same jak w zależności właściwej dla stosunku pracy. Nie może jednak występować sytuacja, gdy zleceniobiorca przy wykonywaniu usługi pozostaje pod permanentnym kierownictwem zleceniodawcy, udzielającym mu szczegółowych poleceń co do sposobu wykonywania czynności (Prusinowski 2012, 65-66).

W przypadku umowy o pracę wynagrodzenie jest koniecznym elementem umowy i pracownik nie może zrzec się prawa do wynagrodzenia ani przenieść 
tego prawa na inną osobę (art. 84 ustawy z 26.06.1974 r. - Kodeks pracy, Dz.U. z 2018 r., poz. 917 ze zm.). Zlecenie natomiast jest co do zasady odpłatne, ale z umowy lub okoliczności sprawy może wynikać, że przyjmujący zlecenie zobowiązał się wykonać je bez wynagrodzenia (art. $735 \S 1$ Kodeksu cywilnego). W sytuacji braku odmiennej umowy lub obowiązującej taryfy należy się „wynagrodzenie odpowiadające wykonanej pracy”. Trzeba wskazać, że w obrocie gospodarczym, gdy zleceniodawca wykonuje zlecenie w ramach działalności zawodowej, zlecenie w zasadzie zawsze ma charakter odpłatny. Nieodpłatne umowy zlecenia natomiast występują np. w stosunkach rodzinnych, sąsiedzkich czy wśród bliskich znajomych i dotyczą pomocy w sprawach życia codziennego.

W przypadku pracownika obowiązek osobistego świadczenia pracy ma charakter bezwzględny, a powierzenie wykonywania jakichkolwiek obowiązków pracowniczych osobie trzeciej jest wykluczone. Zleceniobiorca co do zasady powinien wykonywać czynności osobiście, może jednak powierzyć wykonanie zlecenia osobie trzeciej, jeżeli jest to przewidziane w umowie lub wynika ze zwyczaju albo gdy jest do tego zmuszony przez okoliczności (art. 738 Kodeksu cywilnego). W przypadku takim obowiązany jest zawiadomić niezwłocznie dającego zlecenie o osobie i o miejscu zamieszkania swego zastępcy i w razie zawiadomienia odpowiedzialny jest tylko za brak należytej staranności w wyborze zastępcy. Należy podkreślić, że z ,powierzeniem wykonania zlecenia osobie trzeciej” mamy do czynienia w sytuacji, gdy zleceniobiorca zleca czynności stanowiące przedmiot zlecenia innej osobie w taki sposób, że zastępca samodzielnie decyduje o sposobie oraz przebiegu ich wykonania. Zleceniobiorca może natomiast co do zasady posługiwać się przy wykonaniu zlecenia pomocnikami lub podwykonawcami pozostającymi pod jego kontrolą i nadzorem, chyba że sprzeciwia się temu właściwość świadczenia, np. konieczność zachowania poufności informacji koniecznych do wykonania zlecenia (Drapała 2013).

Moim zdaniem nie jest możliwe korzystanie z pomocy podwykonawcy czy pomocnika np. w przypadku usług polegających na sprawowaniu opieki nad dzieckiem z uwagi na to, że jest to umowa oparta na szczególnym zaufaniu do osoby opiekuna. Status prawny zastępców, podwykonawców i pomocników z punktu widzenia przepisów ubezpieczeniowych jest dyskusyjny.

Obecnie zleceniobiorcy podlegają obowiązkowo ubezpieczeniu emerytalnemu, rentowemu i wypadkowemu (art. 6 i art. 12 SysUbSpołU), ubezpieczenie chorobowe jest natomiast dobrowolne (art. 14 SysUbSpołU). Możliwość przystąpienia do dobrowolnego ubezpieczenia chorobowego jest jednak uwarunkowana istnieniem obowiązku ubezpieczenia emerytalnego i rentowego. $\mathrm{Z}$ ubezpieczenia tego nie mogą zatem skorzystać ci zleceniobiorcy, którzy nie są objęci ubezpieczeniami obowiązkowymi z uwagi na posiadanie innego tytułu ubezpieczenia, jak również uczniowie i studenci do ukończenia 26 lat (art. 6 ust. 4 SysUbSpołU). Objęcie zleceniobiorców dobrowolnym, a nie obowiązkowym ubezpieczeniem chorobowym jest uzasadnione specyfiką pracy wykonywanej na podstawie umowy 
zlecenia, a przede wszystkim brakiem bezwzględnego obowiązku osobistego jej wykonywania. Czasowa niezdolność do pracy zleceniobiorcy nie musi oznaczać utraty dochodu, ponieważ nie jest on podporządkowany w takim stopniu jak pracownik i może dostosować sposób wykonywania pracy do ograniczeń wynikających z choroby. Może również korzystać z pomocy innych osób oraz z zastępców.

Dodatkowo należy wskazać, że w przypadku zlecenia może wystąpić wielość podmiotów zarówno po stronie dającego, jak i przyjmującego zlecenie, co nie może mieć miejsca przy umowie o pracę, gdzie po każdej ze stron może występować tylko jeden podmiot.

Zgodnie z art. 6 ust. 1 pkt 4 SysUbSpołU, ubezpieczeniem społecznym objęte są również osoby współpracujące ze zleceniobiorcami. Za osobę współpracującą uważa się małżonka, dzieci własne, dzieci drugiego małżonka i dzieci przysposobione, rodziców, macochę i ojczyma oraz osoby przysposabiające, jeżeli pozostają ze zleceniobiorcą we wspólnym gospodarstwie domowym i współpracują przy wykonywaniu umowy zlecenia (art. 8 ust. 11 SysUbSpołU).

Przenosząc to pojęcie na grunt prawa cywilnego, można przyjąć, że wykonywanie zlecenia z pomocą osoby współpracującej nie oznacza powierzenia zlecenia osobie trzeciej, ale jest równoznaczne z posługiwaniem się przy wykonaniu zlecenia pomocnikiem lub podwykonawcą pozostającym pod kontrolą i nadzorem zleceniobiorcy. Dopuszczalność korzystania z pomocy osoby współpracującej zależy od treści umowy zlecenia i okoliczności konkretnej sprawy. Istotne jest to, że nie ma żadnego stosunku prawnego pomiędzy zleceniodawcą a osobą współpracującą. Zleceniobiorca nie musi powiadamiać zleceniodawcy o fakcie współpracy i sam ponosi odpowiedzialność za wykonanie całości zlecenia ${ }^{1}$.

Konstrukcja osoby współpracującej upodabnia ubezpieczenie społeczne zleceniobiorców do ubezpieczenia społecznego przedsiębiorców, choć ustawodawca zróżnicował zasady w zakresie obliczania i finansowania składek dla osób współpracujących w obu tych przypadkach. Dla współpracujących z przedsiębiorcami podstawą wymiaru składek jest zadeklarowana kwota, nie niższa niż minimalna podstawa dla przedsiębiorców, natomiast dla osób współpracujących ze zleceniobiorcami - zadeklarowana kwota, nie niższa niż minimalne wynagrodzenie (art. 18 ust. 7 SysUbSpołU).

Składki na ubezpieczenia społeczne osób współpracujących z przedsiębiorcą finansuje w całości płatnik - czyli przedsiębiorca, natomiast składki na ubezpieczenia społeczne osób współpracujących ze zleceniobiorcami są finansowane w odpowiednich częściach przez płatnika i ubezpieczonego, na takich samych zasadach jak składki pracownicze (art. 16 ust. 1 pkt 9 SysUbSpołU). Takie rozwiązanie budzi wątpliwości, ponieważ przy współpracy nie mamy do czynienia

${ }^{1} \mathrm{~W}$ poprzednio obowiązujących przepisach osoba współpracująca ze zleceniobiorcą była objęta ubezpieczeniem, jeżeli jednostka będąca zleceniodawcą wyraziła zgodę na współpracę - art. 29 ustawy z 19.12.1975 r. o ubezpieczeniu społecznym osób wykonujących pracę na podstawie umowy agencyjnej lub umowy zlecenia (Dz.U. z 1995 r. Nr 65, poz. 333 ze zm.). 
z wynagrodzeniem, lecz ze wspólnym wypracowywaniem przychodu, który formalnie jest wypłacany zleceniobiorcy, ale wchodzi do wspólnego, rodzinnego budżetu (tak jak przy współpracy przy działalności gospodarczej). Nie wiadomo zatem, w jaki sposób osoba współpracująca miałaby finansować swoją część składek.

Ustawa systemowa nie zawiera jednoznacznego przepisu określającego, kto jest płatnikiem składek za osobę współpracującą ze zleceniobiorcą. W przypadku współpracy z osobą prowadzącą działalność gospodarczą jednoznacznie wskazano, że jest to osoba prowadząca działalność. W przypadku zleceniobiorców i osób współpracujących pozostaje ogólna formuła zawarta w art. 4 pkt 2 lit. a SysUbSpołU, zgodnie z którą płatnikiem jest ,jednostka organizacyjna lub osoba fizyczna pozostająca $\mathrm{z}$ inną osobą fizyczną w stosunku prawnym uzasadniającym objęcie tej osoby ubezpieczeniami społecznymi”. O ile w przypadku zleceniobiorców nie budzi wątpliwości, że taką jednostką czy osobą jest zleceniodawca, o tyle w przypadku osób współpracujących ze zleceniobiorcami trudno określić płatnika na podstawie przytoczonej definicji.

$\mathrm{Z}$ zasad logiki wynika, że płatnikiem, a zatem osobą zobowiązaną do zgłoszenia osoby współpracującej do ubezpieczeń oraz do naliczania i opłacania składek jest zleceniobiorca (a nie zleceniodawca) - analogicznie jak przy współpracy przy prowadzeniu działalności gospodarczej. Trudno jednak wskazać stosunek prawny, jaki łączy zleceniobiorcę z osobą współpracującą, skoro podstawą powstania obowiązku ubezpieczenia w przypadku osób współpracujących nie jest czynność prawna, ale faktyczna współpraca (wyrok SA w Gdańsku z 19.10.2015 r., II AUa 766/15, LEX nr 1842220).

Nie jest możliwe ustalenie, czy w praktyce jest w ogóle stosowana konstrukcja współpracy przy wykonywaniu umowy zlecenia, ponieważ w Portalu Statystycznym ZUS osoby współpracujące są wykazywane łącznie ze zleceniobiorcami (chociaż są zgłaszane do ubezpieczeń z odrębnym kodem, więc ich wyodrębnienie nie byłoby trudne). Brakuje jednak jakiegokolwiek orzecznictwa w tej kwestii - przy bogatym orzecznictwie dotyczącym innych tytułów ubezpieczenia, w tym współpracy przy prowadzeniu działalności gospodarczej - co pozwala przypuszczać, że konstrukcja współpracy ze zleceniobiorcą jest wykorzystywana w praktyce w znikomym stopniu (o ile w ogóle).

Jak już było wspomniane, w Kodeksie cywilnym przewidziana jest możliwość występowania wielości podmiotów zarówno po stronie dającego, jak i przyjmującego zlecenie (art. 745 Kodeksu cywilnego). W sferze ubezpieczeń społecznych taka sytuacja może powodować trudności w określeniu praw i obowiązków poszczególnych podmiotów.

Jeżeli więcej niż jeden podmiot jest zleceniodawcą, a zleceniobiorcą jest osoba fizyczna, to w zasadzie zleceniobiorca powinien zostać zgłoszony do ubezpieczeń społecznych przez obydwu zleceniodawców, a kwota wynagrodzenia stanowiąca podstawę wymiaru składek powinna zostać „podzielona” pomiędzy 
obu zleceniodawców w zależności od tego, w jakiej części każdy z nich pokrywa wynagrodzenie zleceniobiorcy.

Jeżeli po stronie zleceniobiorcy występuje więcej niż jedna osoba fizyczna, to każda $\mathrm{z}$ tych osób posiada własny tytułu ubezpieczenia, a podstawę wymiaru składek stanowi wynagrodzenie przypadające każdemu zleceniobiorcy w wyniku podziału kwoty wypłaconej przez zleceniodawcę. Należy wskazać, że w takiej sytuacji każdy zleceniobiorca ma prawo do minimalnej stawki godzinowej - art. 8 a ust. 3 ustawy z 10.10.2002 r. o minimalnym wynagrodzeniu za pracę (t.j. Dz.U. z 2015 r., poz. 2008 ze zm.). Zasada ta ma zapewne zapobiec omijaniu przepisów o minimalnej stawce godzinowej poprzez fikcyjne zawieranie umowy z kilkoma zleceniobiorcami.

Zleceniobiorca może również przy wykonywaniu umowy posługiwać się pomocnikami i podwykonawcami, chyba że co innego wynika z umowy. Jak już było wspomniane, pomocnik i podwykonawca może być osobą współpracującą ze zleceniobiorcą, jeśli spełnia warunki wskazane w art. 8 ust. 11 ustawy systemowej. Wówczas obowiązek ubezpieczenia powstaje z mocy prawa $\mathrm{z}$ chwilą rozpoczęcia współpracy i trwa do chwili jej zakończenia. W innym przypadku mamy do czynienia $z$ dwoma odrębnymi stosunkami prawnymi: umową zlecenia pomiędzy zleceniodawcą a zleceniobiorcą oraz umową (niekoniecznie zlecenia) pomiędzy zleceniobiorcą a podwykonawcą lub pomocnikiem.

Posługiwanie się przy wykonywaniu umowy pomocnikami i podwykonawcami nie wpływa, moim zdaniem, na obowiązek ubezpieczenia społecznego zleceniobiorcy. Osoby te bowiem pracują pod kontrolą i nadzorem zleceniobiorcy. Zleceniobiorca nadal wykonuje pracę na podstawie umowy zlecenia, tyle że jego praca polega na organizowaniu i nadzorowaniu pracy pomocników lub podwykonawców. Podstawą wymiaru składek na ubezpieczenie zleceniobiorcy jest wynagrodzenie wypłacone mu przez zleceniodawcę, bez znaczenia jest w tym przypadku kwestia rozliczeń pomiędzy zleceniobiorcą a pomocnikami lub podwykonawcami. Z kolei zleceniobiorca może być zleceniodawcą dla pomocnika lub podwykonawcy, o ile łącząca ich umowa jest umową, o której mowa w art. 734 lub art. 750 Kodeksu cywilnego, a wówczas pomocnik lub podwykonawca podlega $\mathrm{z}$ tytułu tej umowy ubezpieczeniom społecznym ${ }^{2}$.

Inna sytuacja występuje w przypadku, gdy zleceniobiorca powierza zastępcze wykonanie zlecenia osobie trzeciej, zwanej zastępcą lub substytutem. Zastępca wykonuje bowiem zlecenie nie obok, ale zamiast zleceniobiorcy. Zleceniobiorca powinien powiadomić zleceniodawcę o osobie substytuta i jego miejscu zamieszkania (art. $738 \S 1$ zdanie drugie Kodeksu cywilnego), a zastępcę powinien poinformować o okolicznościach, w jakich zlecenie jest wykonywane, a także o dotychczasowych wskazówkach co do prowadzenia sprawy, udzielonych przez

${ }^{2}$ Oczywiście, o ile nie będzie miał innego tytułu ubezpieczenia wyłączającego obowiązek ubezpieczenia. 
zleceniodawcę. W razie niedochowania przez zastępcę należytej staranności dający zlecenie może dochodzić naprawienia szkody bezpośrednio od zastępcy. Dający zlecenie nie odpowiada natomiast wobec zastępcy za zapłatę należnego mu wynagrodzenia (wyrok SN z 19.08.1971 r., I CR 300/71, OSNCP 1972, nr 4, poz. 70 ). W przypadkach ustanowienia zastępcy natomiast, pomimo braku przesłanek z art. 738 § 1 zdanie pierwsze Kodeksu cywilnego (tzw. niedozwolona substytucja) lub niedokonania zawiadomienia, przyjmujący zleceniodawca odpowiada za działania i zaniechania substytuta jak za własne (art. 474 Kodeksu cywilnego).

W praktyce zdarza się, że zleceniobiorcy korzystają z zastępstwa w przypadku niezdolności do wykonywania pracy spowodowanej chorobą, w szczególności gdy nie są objęci ubezpieczeniem chorobowym lub nie chcą korzystać ze zwolnień lekarskich z obawy przed utratą źródła utrzymania. Często czynią to wbrew postanowieniom umowy zlecenia, która wyraźnie przewiduje obowiązek osobistego wykonywania pracy, lub nie informują zleceniobiorcy o tym, że faktycznie pracę świadczy inna osoba. Zastępca $z$ reguły jest członkiem rodziny i pomaga zleceniobiorcy nieodpłatnie. $Z$ kolei zleceniodawcy z reguły tolerują fakt niedozwolonej substytucji, zwłaszcza gdy praca wykonywana jest w „terenie”, tj. poza siedzibą zleceniobiorcy, a jej wykonywanie nie wymaga dostępu do informacji poufnych (np. rozlepianie plakatów, ogłoszeń itp.). Zleceniobiorcę na ogół interesuje bowiem tylko to, aby zadania zostały wykonane, a nie to, przez kogo są wykonywane.

Rozważmy, jakie skutki w sferze ubezpieczeń społecznych wywiera powierzenie wykonania zlecenia osobie trzeciej. W myśl art. 13 pkt 2 ustawy systemowej, zleceniobiorcy podlegają obowiązkowym ubezpieczeniom społecznym od dnia oznaczonego w umowie jako dzień rozpoczęcia jej wykonywania do dnia rozwiązania lub wygaśnięcia tej umowy. Zatem dla celów ustalenia obowiązku ubezpieczenia nie ma znaczenia, czy umowa jest faktycznie wykonywana i przez kogo jest wykonywana. $Z$ tego wynika, że powierzenie wykonywania zlecenia osobie trzeciej nie ma wpływu na sytuację prawną zleceniobiorcy w sferze ubezpieczeniowej. Nie można przyjąć, że substytut wchodzi w miejsce zleceniobiorcy i że wykonywanie pracy powierzonej mu przez zleceniobiorcę stanowi dla zastępcy tytuł do ubezpieczenia. Nie ma bowiem odrębnej umowy zlecenia pomiędzy zleceniodawcą a substytutem. Wynagrodzenie formalnie wypłacane jest zleceniobiorcy, choć może ono być następnie przekazywane w całości lub w części zastępcy. Wynagrodzenie to stanowi podstawę wymiaru składek opłacanych za zleceniobiorcę.

Można w tym miejscu dostrzec sprzeczność pomiędzy art. 6 ust. 1 pkt 4 ustawy systemowej, który stanowi, że ubezpieczeniom podlegają osoby wykonujące pracę na podstawie umowy agencyjnej lub umowy zlecenia, a zacytowanym powyżej art. 13 pkt 2 ustawy systemowej, w którym powstanie i ustanie obowiązku ubezpieczenia zostało powiązane z samym istnieniem umowy oraz określoną w niej datą rozpoczęcia pracy, niezależnie od tego, czy praca została faktycznie podjęta przez daną osobę oraz jak długo była wykonywana. Biorąc pod uwagę sam 
art. 6 ust. 1 pkt 4 ustawy systemowej, można postawić tezę, że „martwa” umowa zlecenia, tj. taka, która nie jest faktycznie wykonywana, ale nie została formalnie rozwiązana, nie stanowi tytułu ubezpieczenia ${ }^{3}$. Przy takim założeniu powierzenie wykonywania umowy zastępcy powodowałoby ustanie tytułu ubezpieczenia zleceniobiorcy, ponieważ byłoby równoznaczne z zaprzestaniem wykonywania przez niego pracy na podstawie tej umowy. Takiemu stanowisku przeczy jednak treść powołanego art. 13 pkt 2 ustawy systemowej.

Problem „martwych” umów zlecenia nabiera szczególnego znaczenia w przypadku ubiegania się o zasiłek chorobowy po ustaniu ubezpieczenia przez osoby, które w przeszłości zawarły umowę zlecenia, zaprzestały jej wykonywania, ale nie doszło do rozwiązania tej umowy. Formalnie bowiem umowa ta stanowi tytuł ubezpieczenia chorobowego i uniemożliwia uzyskanie zasiłku chorobowego z innego tytułu (np. zatrudnienia), który ustał (art. 13 z ustawy dnia 25 czerwca 1999 r. o świadczeniach pieniężnych z ubezpieczenia społecznego w razie choroby i macierzyństwa - Dz.U. z 2017 r., poz. 1368 ze zm.). Należy podkreślić, że w art. 746-748 Kodeksu cywilnego wskazano sposoby rozwiązania umowy zlecenia oraz okoliczności powodujące jej wygaśnięcie. Przepisy te nie przewidują wygaśnięcia umowy w wyniku jej niewykonywania per facta concludentia. W wyroku z 17.06.2008 r. (I UK 402/07, OSNP 2009/21-22/297) Sąd Najwyższy zajął stanowisko, że dopiero wykonywanie pracy na podstawie umowy zlecenia - a nie tylko zawarcie umowy - stwarza obowiązek ubezpieczenia emerytalnego i rentowego lub możliwość wyboru tego tytułu ubezpieczenia. Wyrok ten zapadł jednak na tle szczególnej sytuacji faktycznej - umowa zlecenia została uznana za pozorną czynność prawną, która nie mogła stanowić tytułu do objęcia ubezpieczeniem społecznym, ponieważ jej rzeczywistym celem było skorzystanie przez zleceniobiorcę z możliwości opłacania składek na ubezpieczenia niższych niż z tytułu prowadzonej jednocześnie działalności gospodarczej. Kwestia „martwych” umów zlecenia (niebędących umowami pozornymi) nie została zatem do tej pory rozstrzygnięta $\mathrm{w}$ orzecznictwie.

Wracając do problemu powierzenia, należy rozważyć szczególną sytuację, gdy zleceniobiorca przebywając na zwolnieniu lekarskim, powierza wykonanie zlecenia zastępcy, a sam pobiera zasiłek chorobowy. Jak się wydaje, takiego zachowania nie można kwalifikować w kategoriach art. 17 ustawy zasiłkowej jako okoliczności powodującej utratę prawa do zasiłku chorobowego. Podstawą do pozbawienia prawa do zasiłku chorobowego w świetle wskazanego przepisu jest osobiste wykonywanie pracy przez zleceniobiorcę, a nie sam fakt otrzymywania wynagrodzenia. Ryzyko ubezpieczeniowe w takim przypadku polega na utracie dochodu spowodowanej koniecznością przekazania całości lub części wynagrodzenia - uzyskanego z tytułu czynności wykonanych w okresie choroby

\footnotetext{
${ }^{3}$ Należy odróżnić „martwą” umowę zlecenia od umowy pozornej, tj. takiej umowy, która z założenia nie miała być wykonywana.
} 
zleceniobiorcy - osobie, która wykonała te czynności zamiast niego. Okoliczność, że zastępca jest osobą bliską, która pomaga zleceniobiorcy nieopłatnie, nie może rzutować na prawo zleceniobiorcy do świadczeń z ubezpieczenia społecznego. Jest to sytuacja analogiczna jak w przypadku osoby prowadzącej działalność gospodarczą, która w trakcie niezdolności do pracy spowodowanej chorobą może nadal uzyskiwać dochód z prowadzonej działalności, wykonując ją przez pracowników lub pełnomocników.

Osobną kwestią jest natomiast podleganie ubezpieczeniu społecznemu przez zastępcę. Będzie to uzależnione od treści umowy pomiędzy zleceniobiorcą a zastępcą. Moim zdaniem, nie jest wykluczone zakwalifikowanie tej umowy jako umowy zlecenia stanowiącej dla substytuta tytuł ubezpieczenia. W niektórych sytuacjach, np. w przypadku bardzo częstych zwolnień lekarskich zleceniobiorcy i wyręczenia go przez osoby bliskie spełniające warunki do uznania za osoby współpracujące, można rozważyć objęcie tych osób ubezpieczeniem jako osób współpracujących ze zleceniobiorcą.

W praktyce bywa, że umowę już z założenia wykonuje inna osoba niż będąca formalnie zleceniobiorcą - na przykład umowę zawiera osoba, która z uwagi na inny tytuł ubezpieczenia nie jest objęta $\mathrm{z}$ tytułu tej umowy ubezpieczeniem społecznym, a faktycznie pracę zamiast niej wykonuje inna osoba. W takiej sytuacji nie jest teoretycznie wykluczone wydanie przez ZUS decyzji obejmującej ubezpieczeniem społecznym faktycznego zleceniobiorcę. Umowę pomiędzy zleceniodawcą a fikcyjnym zleceniobiorcą można wówczas uznać za czynność pozorną i jako taką za bezwzględnie nieważną, stwierdzając jednocześnie istnienie umowy zlecenia pomiędzy zleceniodawcą a faktycznym wykonawcą umowy. Do tego konieczne jest jednak wykazanie zmowy pomiędzy osobami zainteresowanymi, tj. wykazanie, że zleceniodawca w chwili zawierania umowy wiedział, że nie będzie ona wykonywana przez zleceniobiorcę, ale przez inną osobę, a zgodnym zamiarem stron było uniknięcie lub zmniejszenie obciążeń z tytułu składek. Brak tej zmowy sprawia, że opisaną sytuację można rozpatrywać tylko w kategoriach niedozwolonej substytucji.

Problematyczna jest sytuacja, w której z powodu niedozwolonej substytucji zleceniodawca żąda od zleceniobiorcy zwrotu wypłaconego już wynagrodzenia, od którego naliczył i wykazał składki na ubezpieczenia społeczne. Do rozważenia pozostaje kwestia, czy zleceniobiorca może wówczas skorygować dokumenty rozliczeniowe, wykazując ,zerową” podstawę wymiaru składki i zażądać od ZUS zwrotu nadpłaconych składek.

Moim zdaniem, powyższe problemy wymagają interwencji ustawodawcy. Należy uregulować sytuację prawną w zakresie ubezpieczeń społecznych pomocników, podwykonawców i zastępców, a także sytuację zleceniobiorcy, który przy wykonywaniu umowy został zastąpiony przez substytuta. Przemyślenia wymaga również konstrukcja osoby współpracującej przy wykonywaniu umowy zlecenia. 


\title{
BIBLIOGRAFIA
}

Babińska-Górecka, Renata. 2015. „Ewolucja treści ryzyka socjalnego osób „zatrudnionych” na podstawie umów cywilnoprawnych w ubezpieczeniu społecznym". W Umowy cywilnoprawne w ubezpieczeniach społecznych. Red. nauk. Marzena Szabłowska-Juckiewicz, Monika Wałachowska, Jacek Wantoch-Rekowski. Warszawa: Wolters Kluwer Polska.

Drapała, Przemysław. 2013. „Komentarz do art. 734 Kodeksu cywilnego”. W Kodeks cywilny. Komentarz. Księga trzecia. Zobowiąania. Red. Jacek Gudowski. Warszawa: LexisNexis.

Prusinowski, Piotr. 2012. Umowne podstawy zatrudnienia. Warszawa: Wolters Kluwer Polska.

Joanna Ceglarska-Jóźwiak

\section{CONTRACTOR'S SPECIFIC PROBLEMS OF SOCIAL INSURANCE IN THE CONTEXT OF THE LACK OF THE CONTRACTOR'S OBLIGATION TO PERSONALLY PROVIDE WORK}

\begin{abstract}
The article presents contractor's specific problems of social insurance resulting from the lack of the contractor's absolute obligation to provide work on a personal basis. The analysis covers some situations in which the contractor provides a service through a third party or the contractor is substituted by a third party. Discussed are the effects of using by the contractor the help of other persons in the sphere of social insurance for the contractor themselves and their assistant, subcontractor or replacement. The design of the person cooperating in the performance of the contract for services has also been discussed.
\end{abstract}

Keywords: social insurance, contractor, contract of employment, civil-law contract. 